\title{
СОЦІАЛЬНО-ПЕДАГОГІЧНІ УМОВИ ФОРМУВАННЯ ГОТОВНОСТІ МАЙБУТНІХ СОЦІАЛЬНИХ ПРАЦІВНИКІВ ДО ПАТРОНАЖНОЇ РОБОТИ 3 ЛЮДЬМИ ПОХИЛОГО ВІКУ
}

\author{
Голубенко Т. О.
}

\section{ВСТУП}

Важливою соціальною проблемою XXI століття на світовому рівні та в Україні є створення комфортних умов для людей похилого віку, щоб вони не так вразливо сприймали процес старіння. Значне збільшення частки населення людей літнього та старого віку впливає на всі сфери життєдіяльності суспільства та спонукає освітню систему держави до визначення пріоритетних напрямів щодо соціальної роботи із зазначеною віковою категорією населення.

3 метою посилення уваги українського суспільства до процесу старіння населення та забезпечення гармонізації соціальних відносин між представниками різних поколінь актуальним постає питання підготовки майбутніх соціальних працівників до патронажної роботи 3 людьми похилого віку.

Проблема старіння стала предметом дослідження в низці наукових праць вітчизняних та зарубіжних дослідників, зокрема висвітлені: філософські аспекти старіння, старості та довголіття у працях В. Андрущенка, В. Альперовича, I. Давидовського, О. Тополь, В. Фролькіса та ін.; соціальний супровід старіння - у працях О. Богомольця, I. Мєчнікова та ін.; психологічні аспекти старіння відображені у дослідженнях Б. Ананьєва, М. Александрової, Л. Анциферової, О. Краснової, Х. Порсєвої та ін.; правові та економічні аспекти забезпечення людей похилого віку - у працях Н. Болотіної, О. Мачульської, І. Сироти та ін.; питання трудової реабілітації, профілактики передчасного старіння, соціального самопочуття та адаптації в новому соціумі розкрито у працях М. Срмолаєвої, T. Коленіченко, Р. Яцемірської та ін.; проблеми соціального самопочуття та поведінки людей похилого віку у суспільстві як психолого-педагогічне завдання здоров'язберігаючого напряму, як особистісної і соціальної цінності розглядаються науковцями I. Бєлєнькою, В. Чайковською та ін.; проблеми теоретичної та практичної підготовки фахівців соціальної сфери до роботи 3 різновіковими категоріями населення вивчають С. Архипова, О. Безпалько, В. Бех, Р. Вайнола, Л. Завацька, І. Звєрєва, А. Капська, 
О. Карпенко, I. Козубовська, Г. Лактіонова, Л. Міщик, I. Мигович, I. Пєша, Ж. Петрочко, В. Поліщук, В. Полтавець, С. Харченко та ін.

Для оптимізації навчально-виховного процесу та прийняття найкращого науково-методичного рішення, який б найбільш продуктивно сприяв формуванню готовності майбутніх соціальних працівників до патронажної роботи 3 людьми похилого віку на фундаменті оволодіння студентами основними соціальними, педагогічними знаннями та вміннями, у дослідженні соціальнопедагогічних умов процесу формування готовності майбутніх соціальних працівників до патронажної роботи з людьми похилого віку представлена сукупністю чотирьох компонентів. Відповідно до них було сформульовано чотири критерії до визначених структурних компонентів. Визначено готовність до патронажної роботи 3 людьми похилого віку як соціально-психологічний та професійний прояв студентами зв'язку професійної спрямованості з іншими важливими властивостями особистості, що передбачає сформованість моральних цінностей, інтелектуальних якостей, знань, умінь i навичок до здійснення патронажної роботи з людьми похилого віку. Доведено, що в ході аналізу даних щодо оцінки готовності майбутніх соціальних працівників до патронажної роботи з людьми похилого віку є переваги сформованості показників готовності за чотирма критеріями, які полягають в особистісно-орієнтованій підготовці, формуванні практичного спрямування в процесі формування готовності майбутніх соціальних працівників до зазначеного виду професійної діяльності.

\section{1. Науково-методичне забезпечення підготовки майбутніх соціальних працівників до патронажної роботи з людьми похилого віку}

Одним із завдань нашого дослідження було визначено обгрунтування та експериментальна перевірка спроектованого змісту навчання майбутніх соціальних працівників до патронажної роботи 3 людьми похилого віку і його науково-методичного забезпечення. Із цією метою ми використали моделювання, яке є невід'ємним аспектом під час забезпечення природної єдності навчання та наукових досліджень у педагогічному процесі. Методологія моделювання передбачає вивчення складних систем, до яких відноситься i педагогічна освіта, й водночас дозволяє здійснити планування, розвиток та визначити умови iї успішного функціонування у євроінтеграційному просторі ${ }^{1}$.

Повідайчик О.С. Формування інформаційної культури майбутнього соціального працівника в процесі професійної підготовки: автореф. дис. ... канд. пед. наук: спец. : 13.00.04 ; Ужгородський нац. ун-т. Тернопіль, 2007. С. 13, 27. 
Ми погоджуємось 3 автором О. Карпенко, що без визначення моделі підготовки спеціаліста важко говорити про створення адекватної моделі навчання, розробки змісту, форм і методів професійної освіти студентів та моделі діяльності соціального працівника. Модель можна розглядати як ідеальне відображення реальних процесів, що протікають у системі педагогічної освіти 2 .

Моделювання - це матеріальне або уявне, ізоморфне імітування реально наявної системи шляхом створення спеціальних аналогів (моделей), у яких відтворюються принципи організації й функціонування системи. За допомогою моделювання можливе відволікання від деяких складових системи, які виступають як несуттєві в даному конкретному випадку. Використовуючи моделювання, можна, перейти від аналітичного вивчення окремих властивостей, форм і процесів до синтетичного пізнання цілісних систем у контрольованих умовах. Саме завдяки спрощенню й схематизації модель допускає точний аналіз і математичний опис, перенос отриманих висновків на реальні умови.

У нашому дослідження модель виступає системоутворюючим чинником вищої освіти та одночасно $є$ основою вдосконалення професійної підготовки майбутніх соціальних працівників для здійснення патронажної роботи з людьми похилого віку.

Сьогодні $\epsilon$ досить відомою i має право на життя саме трьохкомпонентна структурована модель А. Мудрик, в якій наявний:

1) мотиваційний компонент - мотиви, які спонукають до діяльності в системі інформаційного суспільства через прагнення саморозвитку та самоактуалізації;

2) когнітивний компонент, що відображає сформованість умінь, необхідних для виконання функцій, які ставить перед працівником інформаційне суспільство, формування компетентності, тобто уміння пристосовуватися до нових технологій (здійснювати рецепцію та трансфер технологій) за рахунок рівня освіти;

3) емоційно-вольовий компонент як відчуття, пов'язані 3 виконанням роботи та рішення, які приймає суб'єкт. Він присутній у тих відчуттях, що пов'язані з діяльністю та прийняттям рішень в сфері фахової діяльності ${ }^{3}$.

За допомогою моделі можна відобразити результат, який необхідно досягти у процесі навчання майбутніх соціальних працівників

2 Карпенко О.Г. Професійна підготовка соціальних працівників в умовах університетської освіти: науково-методичний та організаційно-технологічний аспекти : монографія. / за ред. С.Я. Харченко. Дрогобич : Коло, 2007. С. 118.

${ }^{3}$ Мудрик А.В. Социальнаяпедагогика: учеб.пособ. Москва : Академия, 2002. C. 4-6. 
патронажній роботі 3 людьми похилого віку при послідовному засвоєнні знань, умінь та навичок, що забезпечує усвідомлення майбутнім фахівцем особливостей патронажної роботи 3 людьми похилого віку. Таким чином, моделювання ситуацій забезпечує розвиток у студентів готовності до патронажної роботи з людьми похилого віку. У структурі моделі вміщується мета, завдання, педагогічні умови, функції та принципи досягнення кінцевого результату.

Спираючись на системний підхід, ми маємо можливість виокремити елементи системи для окреслення кінцевого результату у процесі побудови моделі.

У зв'язку з розширенням діапазону соціальної сфери та її напрямів і видів діяльності, постає потреба в підготовці фахівців для здійснення патронажної роботи 3 людьми похилого віку, які потребують сторонньої допомоги. Під час з'ясування концептуальних засад підготовки майбутніх соціальних працівників до патронажної роботи 3 людьми похилого віку простежується прогностичний та випереджувальний характер трансформації соціальної сфери та іiі інфраструктури на сучасному етапі.

У процесі формування готовності майбутніх соціальних працівників до патронажної роботи з людьми похилого віку відбувається науковий пошук для створення та побудови такої моделі, яка відображає зміст майбутньої професійної діяльності. У структурі загальної професійної підготовки соціальних працівників слід зазначити підготовку майбутніх фахівців соціальної роботи щодо здійснення патронажної роботи 3 людьми похилого віку. Орієнтованість процесу підготовки майбутніх соціальних працівників на здійснення патронажної роботи 3 людьми похилого віку передбачає, по-перше, надання загальнометодичних знань про патронажну роботу; по-друге, розкриття змісту та особливостей патронажної роботи як одного 3 пріоритетних напрямів соціальної роботи; по-третє, врахування особливостей соціально-психологічного портрету людини похилого віку; почетверте, забезпечення обізнаності студентів щодо нормативноправового регулювання патронажної роботи з людьми похилого віку; по-п'яте, сприяння усвідомленню студентами доцільності створення соціальних інститутів для здійснення патронажної роботи з людьми похилого віку. Виходячи 3 вищезазначеного, нами спроектовано структурно-функціональну модель, яка розкриває зміст підготовки соціального працівника до патронажної роботи 3 людьми похилого віку, що представляє одну із структурних підсистем професійної підготовки соціальних працівників 
Зазначені критерії відображають мотиваційно-ціннісні аспекти, професійні якості, особистісні якості, професійну спрямованість особи, а також професійні знання, уміння та навички соціального працівника, який спроможний до здійснення патронажної роботи 3 людьми похилого віку.

Проектуючи експериментальну роботу, ми вважали за доцільне окреслити етапи, цілі і методи професійної підготовки студентів до практичної діяльності у соціальній сфері з орієнтацією на проведення патронажної роботи 3 людьми похилого віку. Суть і логіка даного процесу відображено в таблиці 1 .

Таблиця 1

Етапи експериментальної роботи

\begin{tabular}{|c|c|c|}
\hline Етапи & Цілі & $\begin{array}{c}\text { Методи } \\
\text { дослідження }\end{array}$ \\
\hline $\begin{array}{c}\text { I етап - } \\
\text { констатувальний }\end{array}$ & $\begin{array}{l}\text { 1. Визначення комплексу } \\
\text { показників готовності } \\
\text { студентів напряму } \\
\text { підготовки «Соціальна } \\
\text { робота» до патронажної } \\
\text { роботи з людьми похилого } \\
\text { віку. } \\
\text { 2. Діагностування } \\
\text { визначених показників. } \\
\text { 3. Виявлення комплексу } \\
\text { ефективних умов } \\
\text { підготовки студентів до } \\
\text { патронажної роботи з } \\
\text { людьми похилого віку. } \\
\text { 4. Розробка змісту курсів } \\
\text { «Соціальна політика в } \\
\text { Україні», «Соціальне } \\
\text { партнерство», модулю } \\
\text { «Технології соціальної } \\
\text { роботи з людьми похилого } \\
\text { віку» навчальної } \\
\text { дисципліни «Технології } \\
\text { соціальної роботи», } \\
\text { «Соціально-медичний } \\
\text { патронаж», організація } \\
\text { експериментальної студії } \\
\text { «Основи патронажної } \\
\text { роботи з людьми похилого } \\
\text { віку» та методичних } \\
\text { посібників, рекомендацій. }\end{array}$ & $\begin{array}{l}\text { 1. Анкетування } \\
\text { студентів. } \\
\text { 2. Спостереження } \\
\text { за організацією } \\
\text { навчального } \\
\text { процесу в ході } \\
\text { вивчення } \\
\text { студентами напряму } \\
\text { підготовки } \\
\text { «Соціальна робота» } \\
\text { загальних та } \\
\text { спеціальних } \\
\text { дисциплін. } \\
\text { 3. Аналіз програм } \\
\text { з соціальної роботи, } \\
\text { педагогіки й } \\
\text { психологї̈, } \\
\text { соціології, } \\
\text { правознавства, } \\
\text { змісту навчальних } \\
\text { курсів. } \\
\text { 4. Тестування } \\
\text { (О.Карпенко, } \\
\text { Н.Крилов, } \\
\text { М.Рокич). } \\
\text { 5. Проектування } \\
\text { моделі патронажної } \\
\text { роботи з людьми } \\
\text { похилого віку. }\end{array}$ \\
\hline
\end{tabular}


Закінчення таблиці 1

\begin{tabular}{|c|c|c|}
\hline Етапи & Цілі & $\begin{array}{c}\text { Методи } \\
\text { дослідження }\end{array}$ \\
\hline $\begin{array}{c}\text { II - етап } \\
\text { (навчальний) }\end{array}$ & $\begin{array}{l}\text { Експериментальна } \\
\text { перевірка впливу соціально- } \\
\text { педагогічних умов на рівень } \\
\text { формування готовності } \\
\text { майбутніх соціальних } \\
\text { працівників до патронажної } \\
\text { роботи з людьми похилого } \\
\text { віку }\end{array}$ & $\begin{array}{l}\text { 1. Формувальний } \\
\text { експеримент. } \\
\text { 2. Тестування. } \\
\text { 3. Отримання } \\
\text { результату. } \\
\text { 4. Самооцінка. }\end{array}$ \\
\hline $\begin{array}{c}\text { III етап- } \\
\text { контрольний }\end{array}$ & $\begin{array}{l}\text { 1.Теоретичне осмислення } \\
\text { дослідно- } \\
\text { експериментальних даних, } \\
\text { їх аналіз та інтерпретація. } \\
\text { 2.Оформлення результатів, } \\
\text { формулювання висновків. } \\
\text { 3. Розробка навчальних } \\
\text { посібників, методичних } \\
\text { рекомендацій щодо } \\
\text { організації ефективного } \\
\text { формування готовності } \\
\text { майбутніх соціальних } \\
\text { працівників до патронажної } \\
\text { роботи з людьми похилого } \\
\text { віку. }\end{array}$ & $\begin{array}{l}\text { 1. Експеримент. } \\
\text { 2. Метод } \\
\text { спостереження. } \\
\text { 3. Оцінка } \\
\text { результату. } \\
\text { 4. Метод } \\
\text { математичної } \\
\text { обробки } \\
\text { результатів. }\end{array}$ \\
\hline
\end{tabular}

Одним із дієвих засобів у плані навчання майбутніх соціальних працівників, підготовки іiі до професійної життєдіяльності $\epsilon$ міжпредметні зв'язки як обов'язковий елемент навчального процесу. Вони сприяють формуванню цілісного розуміння студентами ролі i місця наук у загальному освітньому процесі, їх взаємовідносин і меж їх застосування.

Проблема встановлення міжпредметних зв'язків $\epsilon$ однією iз важливих проблем в організації навчально-виховного процесу. Мету впровадження міжпредметних зв'язків при підготовці майбутніх соціальних працівників до патронажної роботи з людьми похилого віку ми визначили як забезпечення логічного зв'язку при вивченні всіх предметів за навчальним планом, оволодіння формами і змістом навчання відповідно до вимог кваліфікаційної характеристики.

Розглянемо структуру готовності майбутніх соціальних працівників до патронажної роботи 3 людьми похилого віку в процесі нашого дослідження. Покращення якості підготовки майбутніх соціальних працівників до патронажної роботи з людьми похилого віку потребує вдосконалення навчально-виховного процесу. 
Встановлення зв'язків між предметами загальнонаукового i професійно-практичного циклу.

Виявлення ефективних шляхів, форм і засобів встановлення зв 'язків у процесі вивчення кожного навчального предмету та зв'язків між теоретичним i практичним навчанням, що дозволяє майбутнім соціальним працівникам вміло, творчо вирішувати проблеми людей похилого віку відповідно до сучасних вимог соціальної роботи.

Здійснення міжпредметних зв'язків реалізується за такими основними напрямками: а) необхідність використання знань, умінь та навичок студентів із загальноосвітніх предметів при вивченні професійно орієнтованих предметів; б) використання знань, умінь i навичок студентів із спеціальних предметів при вивченні загальноосвітніх дисциплін; в) розробка карток - завдань професійного спрямування напрямку із загальнонаукових циклів;г) виготовлення комплексних посібників з використанням міжпредметних зв'язків; д) розробка i впровадження комплексних завдань на період проходження практики студентами.

Зв'язок загальнонаукових і професійно-орієнтованих предметів дуже важлива проблема, використання якої допоможе всебічному вивченню патронажної роботи 3 людьми похилого віку. Цим в основному і викликана необхідність виявлення і використання більш глибоких і обгрунтованих зв'язків як між окремими темами, так і між різними предметами.

Міжпредметні зв'язки конкретизують знання, необхідні у патронажній роботі з людьми похилого віку, пронизують усі види i форми навчально-виховного процесу, що підтверджується положенням С. Гончаренка: міжпредметні зв'язки відображають комплексний підхід до виховання й навчання, що дозволяє виділити як головні елементи змісту освіти, так і взаємозв'язки між навчальними предметами. На будь-якому етапі навчання міжпредметні зв'язки виконують виховну, розвиваючу й детермінуючу функцію, оскільки підвищують продуктивність перебігу психічних процесів ${ }^{4}$.

На нашу думку, якщо процес навчання побудований правильно, то здійснюється цілеспрямована робота студентів, що дає прогнозований результат, а засвоєні знання перетворюються студентом в значущу для нього систему і у нього з'являється стійкий інтерес до того, що він робить, а також $є$ стимулом до самостійної навчальної діяльності ${ }^{5}$.

4 Гончаренко С.У. Педагогічні дослідження: Методологічні поради молодим науковцям. Київ; Вінниця : ДОВ «Вінниця», 2008. С. 210.

${ }^{5}$ Соціальна педагогіка : підруч. / за ред. проф. А.Й. Капської. Київ : Центр учбової літератури, 2009. 488 с. 
Вітчизняні науковці I. Звєрєва, М. Лукашевич, В. Поліщук розглядають міжпредметні зв'язки та пропонують класифікацію за об'єктом, на основі якого встановлюються зв'язки між навчальними дисциплінами, виходячи зі спільності структури навчальних предметів і структури навчального виховного процесу. Це дозволило нам розрізнити такі типи взаємозв'язків:

1) за змістом навчального матеріалу (змістовно-інформаційні). Так, навчальна дисципліна «Філософія» - I курс, розкриває філософську сутність людини та оточуючого соціального середовища; «Психологія»I-III курси, дає змогу пізнати соціально-психологічний портрет людини похилого віку; 2) за уміннями, що формуються у студентів (операційнодіяльнісні) міжпредметні зв'язки сприяють формуванню в майбутніх соціальних працівників системи загальнонаукових умінь, необхідних у патронажній роботі з людьми похилого віку. Наприклад, під час вивчення курсу «Технології соціальної роботи» (III курс) у студента формуються навички та уміння щодо організації патронажної роботи 3 людьми похилого віку, застосовуючи накопичені теоретичні знання 3 таких дисциплін, як «Вступ до спеціальності» (І курс), «Історія соціальної роботи» (I курс), «Теорія соціальної роботи) (II курс), «Соціальна політика в Україні» (І курс). Використання між зазначеними навчальними дисциплінами взаємозв'язків є важливо при формуванні інтегрованої системи умінь до патронажної роботи з людьми похилого віку на основі вивчених навчальних дисциплін; 3) за методами $i$ засобами навчання (організаиійно-методичні), коли відбувається в організаційнометодичному плані використання міжпредметних зв'язків, цілеспрямована орієнтація мислення студентів на використання таких методів, як аналіз, моделювання, аналогія, ідеалізація, уявний експеримент. Зокрема, моделювання комунікативної ситуації (проведення тематичних бесід зі студентами); участь у роботі студії, зокрема створеної нами експериментальної студії «Основи патронажної роботи з людьми похилого віку», у тренінгових програмах (проведений спільно зі студентамиволонтерами групи «Назустріч людям» тренінг у територіальному центрі соціального обслуговування на тему «Захист прав людей похилого віку») може задовольнити різні потреби міжособистісного та ділового спілкування, а також надасть можливість студенту відчути себе у ролі соціального працівника ${ }^{6,7,8,9}$. Студенти оволодівають уміннями на основі

6 Голубенко Т.О. Метод практичних ситуацій в процесі роботи експериментальної студії «Основи патронажної роботи з людьми похилого віку». Київ : НПУ імені М.П. Драгоманова, 2014. 45 с.

${ }^{7}$ Голубенко Т.О. Організація патронажної роботи з людьми похилого віку як складова практики студентів спеціальності «Соціальна робота»: освітньокваліфікаційний рівень «бакалавр». Київ : НПУ імені М.П. Драгоманова, 2014. $134 \mathrm{c}$. 
зразка чи шаблону оформлення ділових документів (лист-договір, програма патронажної роботи з людьми похилого віку, ділове листування тощо). Так, студенти-учасники експериментальної студії «Основи патронажної роботи з людьми похилого віку» набули практичного досвіду при заповненні ділових документів після звернення у територіальний центр соціального обслуговування (надання соціальних послуг) за місцем проживання щодо оформлення людини похилого віку для організації патронажної роботи.

При визначеному взаємозв'язку професійно-орієнтованих знань i умінь процесу професійної підготовки майбутніх соціальних працівників прогнозується, що студенти отримують необхідні знання 3 різних дисциплін про один конкретний об'єкт, а саме людей похилого віку та здійснення патронажної роботи, що забезпечуватиме повноцінну підготовку студента до майбутньої професійної діяльності.

У процесі дослідження нами був впроваджений авторський навчальний курс «Соціально-медичний патронаж» 3 метою отримання студентами грунтовних знань щодо організації патронажної роботи у міждисциплінарній команді. Відповідно до визначеної мети було розроблено адекватні завдання: сформувати мотивацію у студентів до оволодіння знаннями, уміннями та навичками здійснювати патронажну роботу з людьми похилого віку; сприяти засвоєнню студентами обсягу теоретичних знань щодо змісту патронажної роботи з людьми похилого віку; формувати готовність у майбутніх соціальних працівників до патронажної роботи з людьми похилого віку.

Фундаментальною основою для отримання спеціальних знань щодо технологічного аспекту патронажної роботи з людьми похилого віку, нами був розроблений навчальний посібник «Технології соціальної роботи $з$ людьми похилого віку» та впроваджений авторський модуль «Технології соціальної роботи 3 людьми похилого віку» в структурі навчальної дисципліни «Технології соціальної роботи» 10 .

Отже, залежно від педагогічних орієнтирів і ціннісних підстав, формування готовності майбутнього соціального працівника до патронажної роботи з людьми похилого віку відбувається в освітньому середовищі на основі засвоєння поступово теоретичних знань у поєднанні із практичними знаннями в процесі виконання своїх професійних функцій. Під час використання теоретичних знань у виробничій діяльності соціальними працівниками після закінчення ВНЗ

${ }^{8}$ Голубенко Т.О. Основи патронажної роботи з людьми похилого віку. Київ : НПУ імені М.П. Драгоманова, 2014. 135 с.

9 Голубенко Т.О. Технології соціальної роботи з людьми похилого віку : навчальний посібник. Київ : НПУ імені М.П. Драгоманова, 2014. 163 с.

${ }^{10}$ Там само. 
складається не тільки теоретична, а й практична готовність допатронажної роботи з людьми похилого віку, що реалізується у більш якісному іiі здійсненні ${ }^{11,12,13,14}$.

Тому 3 методологічної точки зору практику слід розглядати як базовий компонент особистісно-професійного становлення майбутнього фахівця до професійної діяльності, виступаючи зв'язком між теоретичним навчанням та самостійною роботою студентів. Метою практичної підготовки майбутніх соціальних працівників до патронажної роботи з людьми похилого віку $\epsilon$ формування у них професійних умінь, навичок i особистісних якостей фахівця, необхідних для здійснення даного виду професійної діяльності.

Так, О. Карпенко на основі особистісно-діяльнісного підходу загострює увагу студентів на чотирьох важливих аспектах:

- виокремлення найбільш важливих теоретичних питань, необхідних студентам у практичній діяльності;

- розкриття оптимальних шляхів, способів, форм практичної діяльності, що сприятимуть підвищенню рівня професіоналізму студентів;

- визначення умов, які можуть сприяти поглибленню і розширенню у студентів професійних знань із того чи іншого напрямку соціальної роботи;

- проектування різних форм діяльності студентів, в яких професійно-практичні технології використовуються як спосіб активізації соціальної допомоги і підтримки різних категорій клієнтів ${ }^{15}$.

Отже, реалізація соціально-педагогічних умов ефективного формування готовності майбутніх соціальних працівників до патронажної роботи 3 людьми похилого віку та впровадження низки діагностичних методик дозволяє говорити про доцільність упровадження у навчально-виховний процес визначених нами соціально-педагогічних умов, які впливають на якість підготовки студентів до патронажної роботи у соціальній сфері.

11 Голубенко Т.О. Метод практичних ситуацій в процесі роботи експериментальної студії «Основи патронажної роботи з людьми похилого віку». Київ : НПУ імені М.П. Драгоманова, 2014. 45 с.

12 Голубенко Т.О. Організація патронажної роботи 3 людьми похилого віку як складова практики студентів спеціальності «Соціальна робота»: освітньокваліфікаційний рівень «бакалавр». Київ : НПУ імені М.П. Драгоманова, 2014. 134 с.

${ }_{13}$ Голубенко Т.О. Основи патронажної роботи 3 людьми похилого віку. Київ : НПУ імені М.П. Драгоманова, 2014. 135 с.

14 Голубенко Т.О. Технології соціальної роботи з людьми похилого віку : навчальний посібник. Київ : НПУ імені М.П. Драгоманова, 2014. 163 с.

15 Карпенко О.Г. Професійна підготовка соціальних працівників в умовах університетської освіти: науково-методичний та організаційно-технологічний аспекти : монографія. / за ред. С.Я. Харченко. Дрогобич: Коло, 2007. С. 241. 


\section{2. Аналіз ефективності реалізації соціально-педагогічних умов та науково-методичного забезпечення професійної підготовки майбутніх соціальних працівників до патронажної роботи \\ з людьми похилого віку}

3 метою впровадження означених нами соціально-педагогічних умов, які дозволяють проектувати процес професійної підготовки майбутніх соціальних працівників до патронажної роботи з людьми похилого віку, постала потреба здійснити діагностику готовності студентів до патронажної роботи 3 людьми похилого віку за визначеними критеріями і їх показниками.

Діагностику готовності майбутніх соціальних працівників до патронажної роботи 3 людьми похилого віку нами здійснено, спираючись на зміст структурних компонентів (мотиващійноиіннісного, який представлений світоглядом i спрямованістю особистості, що $\epsilon$ необхідними для здійснення патронажної роботи 3 людьми похилого віку; когнітивно-орієнтаційного, який передбачає отримання загальних знань й уявлень студентів про особливості й умови майбутньої професійної діяльності, її вимогам до особистості; змістово-професійного, що відображає певний рівень професійних знань, умінь та навичок, наявністю когнітивних, комунікативних, конструктивних та організаційних умінь; практично-діяльнісного, який представлений етапами практичної діяльності по формуванню у студентів готовності до патронажної роботи з людьми похилого віку) та критеріїв (ціннісного, інформаційного, компетентнісного, діяльнісного).

Для перевірки ефективності даного дослідження учасників сукупної вибірки було розділено на дві групи: експериментальну (основна вибірка) та контрольну (контрольна вибірка). В основу формування контрольних та експериментальних груп у перебігу експерименту були покладені визначені на констатувальному етапі показники 4-х критеріїв - ціннісного, інформаційного, компетентнісного, діяльнісного.

Нами визначено готовність до патронажної роботи з людьми похилого віку як соціально-психологічний та професійний прояв студентами зв'язку професійної спрямованості з іншими важливими властивостями особистості (світоглядом, життєвими настановами i духовними цінностями, морально-вольовою та емоційною сферами), що передбачає сформованість моральних цінностей, інтелектуальних якостей, знань, умінь і навичок до здійснення патронажної роботи 3 людьми похилого віку ${ }^{16}$.

16 Ананьев Б.Г. Человеккак предмет познания. Л.енинград Изд-во Ленингр. ун-та, 1968. С. 75. 
Усе вищезазначене дозволяє нам стверджувати, що система підготовки майбутніх сочіальних прачівників до патронажної роботи з людьми похилого віку повинна враховувати наступні особливості: готовність $є$ фундаментальною умовою успішного здійснення патронажної роботи 3 людьми похило віку; готовність дозволяє модифікувати дії у випадку появи труднощів, що надзвичайно важливо для успішного вирішення складних ситуацій; готовність детермінує упорядкування процесу патронажної роботи; готовність персоніфікує процес професійної підготовки; готовність забезпечує позитивний ефект підготовленості студентів; професійна готовність - це конкретизація процесу самовираження, самореалізації студента; готовність сприяе професійній ідентифікації та самовизначенню в професії; готовність виступає інтегральним показником ефективності роботи вищого навчального закладу.

Для виявлення шляхів удосконалення професійної підготовки майбутніх соціальних працівників до патронажної роботи $з$ людьми похилого віку необхідно визначити показники готовності, які застосовуються до конкретної професійної діяльності. Це дозволить додати більш чітку спрямованість всьому процесу підготовки фахівця соціальної роботи до патронажної роботи з людьми похилого віку. При цьому показники готовності фахівця мають визначати, по-перше, готовність студентів до патронажної роботи з людьми похилого віку, яка постійно змінюється (забезпечення подвійного випередження поточного соціального замовлення); по-друге, критерії оцінки готовності майбутнього фахівця повинні відбивати специфіку патронажної роботи з людьми похилого віку; по-третє, показники готовності повинні відображати не тільки результат професійної підготовки, але й весь процес становлення фахівця на різних етапах безперервного професійного утворення.

Для забезпечення змістової валідності розробленого нами діагностичного інструментарію проводилося структуроване й напівструктуроване інтерв'ю з експертами, - спеціалістами з соціальної роботи 3 метою виявлення найбільш важливих характеристик досліджуваного явища. На цьому етапі наша мета полягала в тестуванні розробленого інструментарію, а не в отриманні результатів, які могли б бути узагальненими на генеральну сукупність.

3 метою діагностики за ціннісним критерієм було підготовлено авторську анкету «Визначення рівня мотиваційно-ціннісної готовності майбутніх соціальних працівників до патронажної роботи 3 людьми похилого віку, яка включає 5 блоків, що характеризують моральний, соціально-психологічний, організаційний, управлінський та 
інформаційно-пізнавальний аспекти готовності майбутніх соціальних працівників до патронажної роботи з людьми похилого віку.

Для виявлення рівня готовності за показниками інформаційного критерію були використані експертні оцінки зроблені експертами (викладачами та практикуючими спеціалістами). Для більшої об'єктивності такої оцінки кожний результат оцінювався незалежними експертами, а одержані результати усереднювалися шляхом знаходження середнього арифметичного значення.

Максимального успіху в професійній діяльності майбутній соціальний працівник досягне тоді, коли оволодіє відповідними професійними уміннями, прийомами та способами їх реалізації i розвитку. Діагностика знань, умінь та навичок проводилася за допомогою опитувальника «Виявлення рівня професійної компетентності», адаптованого нами до нових умов на базі анкети О. Карпенко ${ }^{17}$. За допомогою цього опитувальника ми визначали рівні готовності майбутніх соціальних працівників до патронажної роботи 3 людьми похилого віку за показниками інформаційного та компетентнісного критеріїв.

Після проведеного детального аналізу стану готовності майбутніх соціальних працівників до патронажної роботи 3 людьми похилого віку результати за середніми значеннями були графічно відображені у рис. 1.

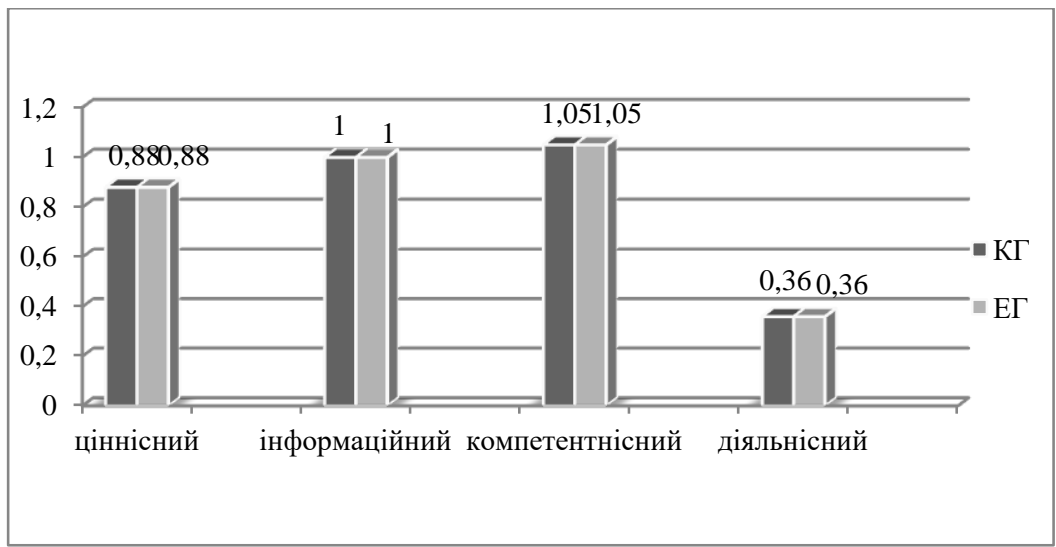

Рис. 1. Оцінка готовності за середніми значеннями майбутніх соціальних працівників до патронажної роботи 3 людьми похилого віку за чотирма критеріями на констатувальному етапі

17 Голубенко Т.О. Метод практичних ситуацій в процесі роботи експериментальної студії «Основи патронажної роботи $з$ людьми похилого віку». Київ : НПУ імені М.П. Драгоманова, 2014. 45 с. 
Проаналізовано реальний стан готовності майбутніх соціальних працівників до патронажної роботи 3 людьми похилого віку за трьома рівнями ціннісного, інформаційного, компетентнісного і діяльнісного критеріїв на констатувальному етапі (див. рис. 2).

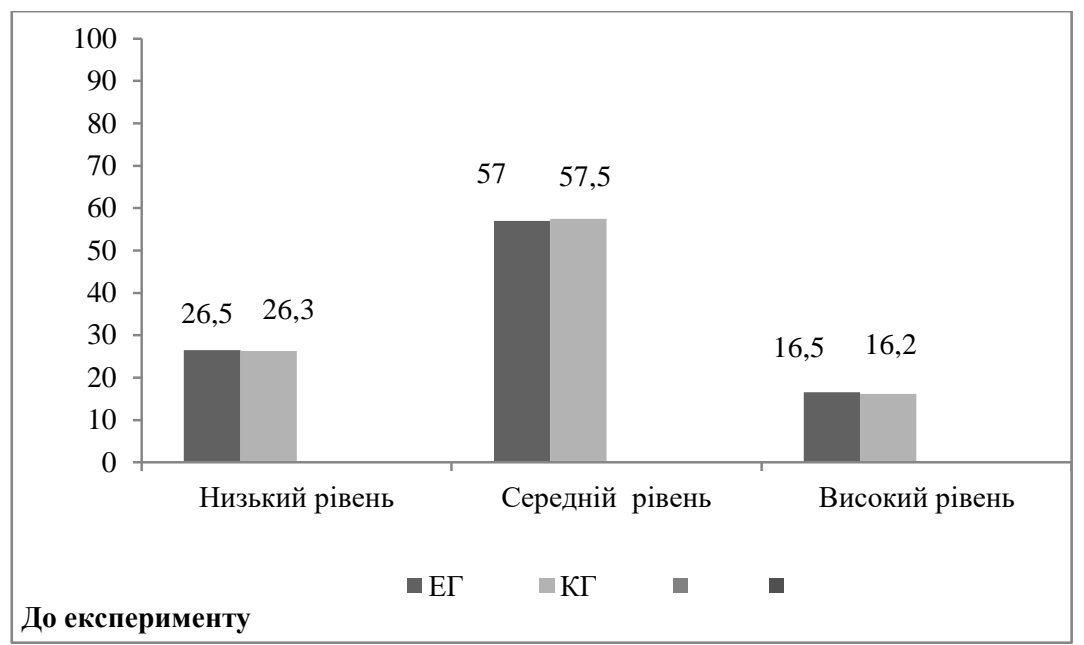

Рис. 2. Показники готовності майбутніх соціальних працівників до патронажної роботи з людьми похилого віку (констатувальний експеримент)

Аналізуючи узагальнені дані констатувального експерименту за трьома рівнями чотирьох критеріїв готовності, можна констатувати:

- низький рівень готовності, який відповідає початковому, в експериментальній групі цей показник має значення 26,5\%, в контрольній групі - 26,3\%,відмінності незначні - лише $0,2 \%$;

- середній рівень готовності студентів до патронажної роботи 3 людьми похилого віку зафіксований в ЕГ на рівні $57,0 \%$, а в КГ - на рівні 57,5\%, відмінності також незначні - 0,5\%;

- показник високого рівня, який відповідає конструктивній готовності, і в експериментальній, і в контрольній групах має незначні розбіжності-0,3\% (ЕГ-16,5\%; КГ - 16,2\%).

Отримані дані засвідчують, що реальний стан готовності майбутніх соціальних працівників до патронажної роботи з людьми похилого віку знаходиться на низькому та середньому рівнях (в ЕГ - 83,5\%; в КГ $-83,8 \%)$.

Така ситуація спонукала до пошуку шляхів і механізмів підвищення рівня готовності майбутніх соціальних працівників до патронажної 
роботи з людьми похилого віку. Із цією метою нами було визначено науково-педагогічні фактори для його реалізації науково-методичне забезпечення процесу формування готовності майбутніх соціальних працівників до патронажної роботи з людьми похилого віку.

На формувальному етапі педагогічного експерименту вирішувалися такі завдання:

1) встановлення факту, що виділені в констатувальному експерименті недоліки в процесі формування готовності майбутніх соціальних працівників до патронажної роботи з людьми похилого віку можуть бути частково чи повністю усунені;

2) проведення оцінювання знань, умінь та навичок, набутих у процесі вивчення впровадженого нами навчального курсу «Соціальномедичний патронаж», авторського модулю «Технології соціальної роботи з людьми похилого віку», створення волонтерської групи «Назустріч людям», організованої експериментальної студії «Основи патронажної роботи з людьми похилого віку» та розробки методичних рекомендацій під час проходження практики студентами під дією активного педагогічного фактору;

3) дослідження динаміки формування готовності майбутніх соціальних працівників до патронажної роботи з людьми похилого віку;

4) визначення статистичної значущості отриманих результатів.

Після формувального експерименту в ЕГ спостерігається, з одного боку, тенденція до збільшення відсотків середнього та високого рівнів за рахунок відсутності низького рівня. У контрольних групах за цим критерієм на констатувальному етапі не було сформованого високого рівня, а на формувальному - незначні зміни в бік зростання (з $0 \%$ до $27,0 \%(57$ oc. $))$.

Помітну динаміку рівнів готовності можна пояснити тим, що при проходженні практики студенти усвідомлювали необхідність її вузької направленості, що проявлялось в ефективному розвитку умінь та навичок.

Завершуючи в цілому вивчення результатів за чотирма запропонованими компонентами, здійснили обрахунок середньостатистичного значення за трьома рівнями готовності та після детального аналізу показників за чотирма критеріями ми можемо узагальнити результати середніх значень та відобразити їх графічно (рис. 3).

Отже, в експериментальній групі виявлена динаміка зміни високого рівня готовності майбутніх соціальних працівників до патронажної роботи з людьми похилого віку. 


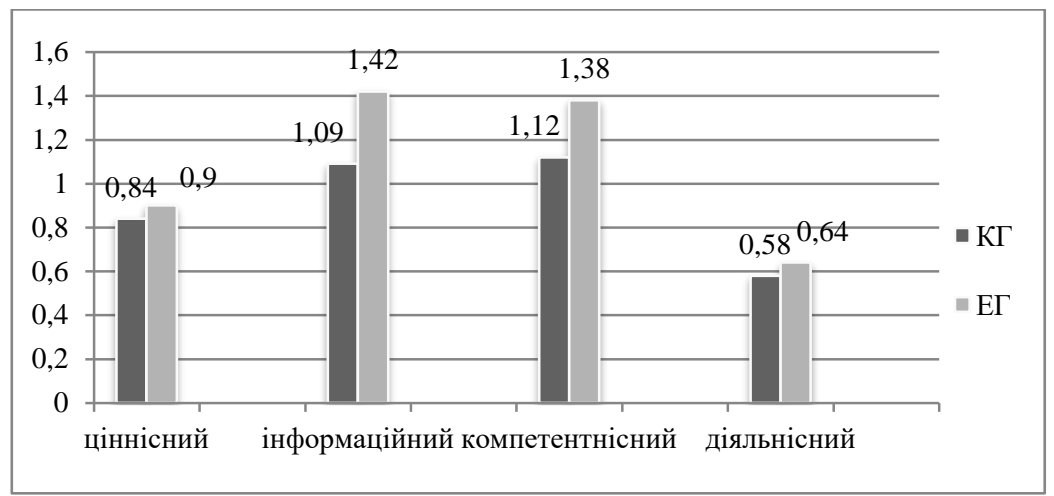

Рис. 3. Динаміка зміни рівнів готовності майбутніх соціальних працівників до патронажної роботи 3 людьми похилого віку за чотирма критеріями в експериментальній групі та в контрольній групі на формувальному етапі

\section{ВИСНОВКИ}

Дослідно-експериментальна апробація визначених нами соціальнопедагогічних умов формування готовності майбутніх соціальних працівників до патронажної роботи з людьми похилого віку дозволили нам сформувати наступні висновки.

По-перше, визначено, що вдосконалення професійної підготовки майбутніх соціальних працівників полягає в тому, що здійснення патронажної роботи 3 людьми похилого віку слід розглядати як особливий вид професійної діяльності, який вимагає спеціальної технологічної системи підготовки.

По-друге, доведено, що формування готовності майбутніх соціальних працівників до патронажної роботи з людьми похилого віку повинне грунтуватись на таких підходах, які забезпечують науково-теоретичну базу, практичне спрямування професійної підготовки. Таким підходами є: системний, особистісно-діяльнісний, особистісно-орієнтований.

По-третє, з метою удосконалення підготовки майбутніх соціальних працівників до патронажної роботи 3 людьми похилого віку ми визначили, запровадили і реалізували чотири соціально-педагогічні умови ефективного формування такої готовності: 1) структурнозмістове наповнення процесу формування готовності майбутніх соціальних працівників до патронажної роботи 3 людьми похилого віку; 2) використання міжпредметних зв'язків навчальних дисциплін у процесі підготовки студентів; 3) науково-методичне забезпечення процесу формування готовності майбутніх соціальних працівників до патронажної роботи з людьми похилого віку; 4) організація практичної діяльності у процесі формування готовності майбутніх соціальних працівників до патронажної роботи з людьми похилого віку. 
По-четверте, розроблено та впроваджено науково-методичне забезпечення для підготовки соціальних працівників до патронажної роботи 3 людьми похилого віку, створено волонтерську групу «Назустріч людям» на базі недержавної організації «Спорт. Єдність. Дружба» м. Київ, експериментальну студію «Основи патронажної роботи з людьми похилого віку».

Результати дослідно-експериментальної роботи підтвердили ефективність виконаного дослідження: у студентів експериментальної групи спостерігається явно виражена зростаюча динаміка готовності до патронажної роботи з людьми похилого віку щодо рівня ії готовності до патронажної роботи 3 людьми похилого віку, у студентів контрольної групи такої динаміки не виявлено.

\section{АНОТАЦІЯ}

У роботі проведено ретельний пошук для оптимізації навчальновиховного процесу таких варіантів прийняття найкращого науковометодичного рішення, який б найбільш продуктивно сприяв формуванню готовності майбутніх соціальних працівників до патронажної роботи 3 людьми похилого віку на фундаменті оволодіння студентами основними соціальними, педагогічними знаннями та вміннями. У дослідженні науково-педагогічних факторів процесу формування готовності майбутніх соціальних працівників до патронажної роботи з людьми похилого віку представлена сукупністю чотирьох компонентів. Відповідно до них було сформульовано чотири критерії до визначених структурних компонентів. Розроблена характеристика рівнів готовності майбутніх соціальних працівників до патронажної роботи з людьми похилого віку шляхом встановлення конкретних ознак, які характеризують прояв їх основних критеріїв: Визначено готовність до патронажної роботи 3 людьми похилого віку як соціально-психологічний та професійний прояв студентами зв'язку професійної спрямованості 3 іншими важливими властивостями особистості, що передбачає сформованість моральних цінностей, інтелектуальних якостей, знань, умінь і навичок до здійснення патронажної роботи 3 людьми похилого віку. Проаналізовано стан готовності майбутніх соціальних працівників до патронажної роботи 3 людьми похилого віку за трьома рівнями ціннісного, інформаційного, компетентнісного i діяльнісного критеріїв на констатувальному та формувальному етапах дослідження.

Доведено, що в ході аналізу даних щодо оцінки готовності майбутніх соціальних працівників до патронажної роботи 3 людьми похилого віку $\epsilon$ переваги сформованості показників готовності за чотирма критеріями, які полягають в особистісно-орієнтованій підготовці, формуванні практичного спрямування в процесі формування готовності майбутніх соціальних працівників до зазначеного виду професійної діяльності. 


\section{ЛITЕРАТУРА}

1. Авербух. Е.С. Расстройства психической деятельности в позднем возрасте: Психиатрический аспект геронтологии и гериатрии. Ленинград : Медицина, Ленингр. отд-е, 1969. 285 с.

2. Ананьев Б.Г. Человеккак предмет познания. Ленинград : Изд-во Ленингр.ун-та, 1968. 340 с.

3. Голубенко T.О. Метод практичних ситуацій в процесі роботи експериментальної студії «Основи патронажної роботи 3 людьми похилого віку». Киев : НПУ імені М.П. Драгоманова, 2014. 45 с.

4. Голубенко T.О. Організація патронажної роботи 3 людьми похилого віку як складова практики студентів спеціальності «Соціальна робота»: освітньо-кваліфікаційний рівень «бакалавр». Киев : НПУ імені М.П. Драгоманова, 2014. 134 с.

5. Голубенко Т.О. Основи патронажної роботи з людьми похилого віку. Київ : НПУ імені М.П. Драгоманова, 2014. 135 с.

6. Голубенко Т.О. Технології соціальної роботи з людьми похилого віку : навчальний посібник. Київ : НПУ імені М.П. Драгоманова, 2014. $163 \mathrm{c}$.

7. Гончаренко С.У. Педагогічні дослідження: Методологічні поради молодим науковцям. Київ; Вінниця : ДОВ «Вінниця», 2008. 278 с.

8. Карпенко О.Г. Професійна підготовка соціальних працівників в умовах університетської освіти: науково-методичний та організаційнотехнологічний аспекти : монографія / за ред. С.Я. Харченко. Дрогобич : Коло, 2007. 374 c.

9. Мудрик А.В. Социальная педагогика : учеб. пособ. Москва : Академия, 2002. 194 с.

10. Повідайчик О.С. Формування інформаційної культури майбутнього соціального працівника в процесі професійної підготовки : автореф. дис. ... канд. пед. наук: спец. : 13.00.04 ; Ужгородський нац. ун-т. Тернопіль, 2007. 20 с.

11. Соціальна педагогіка : підруч. / за ред. проф. А.Й. Капської. Київ : Центр учбової літератури, 2009. 488 с.

\section{Information about the author: Holubenko T. O.,}

Ph.D. in Pedagogic Sciences, Associate Professor, Head of the Department of the Theory and Technology of Social Work Kyiv National Pedagogical University M. P. Dragomanov of Ukraine 9, Pirogov str., Kyiv, Ukraine 